\title{
Sentences Analysis for Development of Speech Perception Test in Infants and Toddlers
}

\author{
Son-A Chang ${ }^{1}$, Min-Hye Lee ${ }^{2}$ \\ 'Department of Speech-Language Therapy \& Aural Rehabilitation, Woosong University, Daejeon, Korea \\ ${ }^{2}$ Department of Speech-Language Pathology, Dankook University, Yongin, Korea
}

\author{
영유아용 말지각 검사 개발을 위한 문장 분석 연구 \\ 장 선 아 $^{1}$ 이 민 혜 ${ }^{2}$ \\ 우송대학교 언어치료청각재활학과 ${ }^{1}$, 단국대학교 언어병리학과 ${ }^{2}$
}

\begin{abstract}
Purpose: The purpose of this study was to analyze and develop the easy sentences for speech perception test using picture stimuli which can be used to the children under 3 years-old. Methods: A total of 102 easy sentences and corresponding picture stimuli were designed for this study. Factors related to semantics, articulatory phonetics, and syntactic structures were analyzed to validate the sentences as for the stimuli of speech perception test for the very young children. Results: The test stimuli contained all the parts of speech and semantic categories. Syllable lengths and phoneme categories were properly distributed and the usage frequency was also acceptable for the very young children. The test sentences can be consisted of 10 test sets which are various enough to mitigate learning effect. Conclusion: This study ensured validity of the test sentences and should be led by further study on validation of the utilizability, parallel test, and reliability as a speech perception test for the very young children.
\end{abstract}

Key Words: Speech perception test, Sentence for infants and toddlers, Picture stimuli.

Received: March 27, 2017 / Revised: April 13, 2017 / Accepted: April 13, 2017

Correspondence: Son-A Chang, Department of Speech-Language Therapy \& Aural Rehabilitation, Woosong University, 171 Dongdaejeon-ro, Dong-gu, Daejeon 34606, Korea

Tel: +82-42-630-9221 / Fax: +82-42-630-9229 / E-mail: parfum0@hanmail.net

\section{INTRODUCTION}

구어 의사소통은 청감각을 통한 말지각 과정을 거쳐 이루어 지며, 정상적인 말과 언어의 발달을 위해서는 듣기 능력, 특히 말지각 능력이 확보되어야 한다. Blamey et al.(2001)은 언어능 력과 청력역치보다 말지각 능력이 구어 발달과 더 높은 상관을 보이는 변수라 하였다. 청각장애가 있는 경우, 제한된 청력으로 인해 소리지각과 말지각 능력에 부정적인 영향을 받을 수 있기 때문에 구어 발달을 포함한 의사소통 발달을 위한 진단 및 중재 과정에서 말지각 능력에 대한 정확한 검사가 반드시 필요하다.

말지각 검사는 들려오는 말소리를 피검자가 얼마나 명료하게 듣는가를 측정하는 검사이다(Korean Audiological Society, 2015). 말지각 검사는 청력 검사의 일종으로 활용될 수 있지만 말소리를 사용하기 때문에 말소리 관련 변인이 검사 결과에 영 향을 미치게 되며, 아동들의 경우 이러한 영향이 더 커지게 된
다. 즉 말지각 능력은 말-언어 발달의 선행조건일 뿐만 아니라 말지각 능력의 발달은 말소리의 이해와 산출 능력의 발달과 서 로 영향을 주고 받으며 진행된다. 발달적 요인은 말지각 검사의 개발에서 중요하게 다루어져야 한다. 뿐만 아니라 검사에 사용 된 어휘의 의미론적 변인과 말소리 자체의 음운론적 변인이 고 려되어야 한다.

발달적 측면에서, 말지각 능력은 신생아와 영아기를 거치는 동안 매우 예민하게 발달한다는 것이 알려져 있다(DeCasper \& Fifer, 1980; Eimas et al., 1971; Trehub, 1976). Werker \& Desjardins(1995)는 음소 변별 실험을 통해 영아들이 말소리의 세밀한 음향적인 부분까지 변별 가능하다는 것을 밝혀냈다. 더 욱 흥미로운 것은, 이런 예민한 말지각 능력이 월령이 증가함에 따라 모국어 음소에 대한 변별 능력의 발달을 중심으로 독특하 게 변한다는 것이다(Best \& McRoberts, 2003; Kajikawa et al., 2006). 따라서 선천성 청각장애는 태아기 때부터 시작하는 매 
우 초기의 말지각 능력 발달에 부정적 영향을 주며 이로 인한 말-언어 발달의 장애가 가중된다.

말지각 능력을 측정하고자 할 때 어린 유아들이나 의사소통 능력에 제한이 있는 대상자의 경우 측정이 불가능하거나 결과 의 신뢰성이 낮다. 생후 1 년 이후에는 심장박동 측정이나 응시 지속시간(looking time) 측정과 같은 심리지각 실험이 어려워 지며, 검사 시행에 필요한 지시 따르기와 자극 반응 절차의 이해 가 성숙하는 만 4 5세가 되기 전까지는 신뢰할 수 있는 검사 반응을 얻기 힘들다. 그 이유로는 일차적으로 검사자의 검사 수행 능력 및 검사 환경 등 검사 관련 요인이 검사 결과에 영향 을 미치며, 피검자의 어휘 및 언어가 발달 중이어서 다양한 양 상을 보이므로 측정이 어렵기 때문이다. 따라서 3세 이하의 아 동들에게는 말지각 검사가 제공되지 못하거나, 보기가 주어지 는 폐쇄형(closed-set) 수준에서의 정보밖에 얻지 못하는 경우 가 발생하게 된다. 또한 아동을 따라 말하게 하기 어려우므로 개방형(open-set) 검사를 시행하기 어려워 음소 수준에서의 말 지각 능력에 대한 정보를 제공할 수 없는 실정이다. 아동이 발 화를 산출할 수 있게 되면 주변의 성인들은 아동이 말소리를 어떻게 지각했는지 확인할 수 있게 된다. 아동들에 대한 말지 각 검사는 아동이 지각한 말소리를 산출할 때 가장 정확하게 이루어질 수 있기 때문에, 발음상의 미성숙을 고려하더라도 아 동들이 지각한 말소리를 산출하도록 하는 것은 말지각뿐만 아 니라 언어 능력의 발달을 측정하는 데에 매우 중요한 방법이다. 따라서 아동들의 검사 자극에 대한 표현 반응을 증가시키기 위 한 시도가 필요하다.

기존에 사용되어 온 영유아용 말지각 검사는 난이도를 낮추 고 그림 자극을 제작하기 쉽도록 대부분 명사 위주로 이루어져 있다. 어휘 발달은 일상생활에서 노출된 어휘에 크게 영향받으 며(Kim et al., 2016), 동사 및 형용사 어휘는 영유아 아동들의 일상생활에서 어휘의 표현을 강화하는 데에 유용하다(Lee, 2009). 따라서 동사 또는 형용사가 포함된 말지각 검사 자극을 이용하면 아동들의 표현 반응을 증가시키는 데 도움이 될 수 있 을 것이다(Robbins, 1994). 명사의 경우 목표어휘에 해당하는 단일 참조물만을 연관지어 습득하면 되지만, 동사 등 다른 범 주의 어휘들은 관계되는 개념들을 이해하여 어휘를 습득하는 복잡성을 지닌다(Davidoff \& Masterson, 1996). Jang(2004)은 컴퓨터 코스웨어 프로그램을 사용하여 움직이는 애니매이션 형태의 그림 자극으로 정신지체 아동들에게 효과적인 학습을 진행할 수 있음을 보고하였다. 이러한 애니매이션 형태의 그림 자극을 사용하는 것은 동사 등의 관계어를 제시할 때 동사의 복잡성을 보충해 줄 적절한 시각적 매체가 될 수 있을 뿐만 아 니라 아동의 흥미와 관심을 끌며 신뢰할 수 있는 반응을 증가 시키기 위한 타당한 방법이 될 수 있을 것이다. 기존의 유아용
말지각 검사가 명사 위주로 구성되어 있는 데에서 탈피하여 다 양한 품사와 의미 구조를 사용한 문장 자극을 사용하여 발달 적 어휘 산출에 따른 말지각 능력을 측정하고, 영유아 아동들 이 듣고 쉽게 선택하거나 따라 말할 수 있는 시각적 자극을 개 발하는 것은 청각 재활에 직결될 수 있는 말지각 검사 도구의 개발에 도움을 줄 수 있을 것이다.

어휘의 품사뿐만 아니라 말지각 검사에 영향을 미치는 의미 론적 변인 중에는 말소리나 어휘의 뜻과 빈도, 난이도 등이 있 다. 어휘들은 서로의 의미범주에 영향을 미치며(Choi, 2000), 영유아들에게 친숙하게 사용되는 어휘들은 고유의 특징을 가 지고 있다(Lee, 2009). 영유아들은 자기 자신과 주변 및 일상생 활과 관련된 어휘들에 제한된 경험을 가지고 있으며, 영유아 말 지각의 특징은 모르는 어휘는 들리지 않는 것과 같은 현상을 보인다는 데에 있다. 따라서 영유아들이 습득한 어휘는 검사에 사용되는 어휘의 범주에 결정적인 영향을 미친다. 한편 유아기 에 들어서면 말소리에 대한 음성적, 음운적 지식이 습득되어 가면서 의미를 몰라도 음성적 수준(phonetic level)에서 말소리 를 산출할 수 있다. 이러한 음성적, 음운적 지식의 발달은 의미 적, 화용적 요인에 의해 강력한 영향을 받으며 또한 어휘 능력 의 발달에 영향을 준다. 따라서 어린 아동들의 말지각은 언어 능력의 범주 내에서 해석되고 접근되어야 하는 것이다.

3세 이하의 아동들은 주변의 어휘에 의해서도 특정 어휘의 수용 및 표현 능력에 영향을 받는다. 음절이 길어질수록 알고 있는 말소리도 지각에 어려움을 가져올 수 있으며, 알고 있는 어휘라도 주변 어휘가 어떤 어휘인가에 따라 상대적으로 듣기 에 어려움이 생기거나 또는 도움을 받을 수 있다. 즉 들어보지 못했거나 어려운 어휘에 대한 반응은 청력 수준에 영향을 미치 는 현상으로 보이게 되는 것이다. 따라서 영유아의 경우 유아용 어휘의 사용이나 고빈도 어휘, 저난이도 어휘를 사용하는 것이 중요하다(Song et al., 2011). 장애아동들은 음절 길이에 따라 수 용 및 산출 능력에 영향을 받는 정도와 기간이 늘어나는 경향 이 있다. 따라서 초기 발달의 특징을 살펴보기 위해서는 짧은 어휘를 중심으로 하여 아동들이 말지각 외에 다른 인지적 처리 에 가질 수 있는 부담을 덜어 주는 것이 필요하다.

또한 말지각 검사에 있어서 음운론적 요소는 어떠한 음소가 사용되었는가, 음소의 배열이 어떠한가를 말하는 것으로, 모음 과 자음의 분포, 음소의 발생 위치 등을 말한다. 우리말의 음소 분포나 아동들이 사용하는 음소 분포의 특성을 반영하는 것은 영유아용 검사의 개발에 있어 중요하다(Byun et al., 2005; Kim \& Shin, 2015). 또한 음소 위치는 음소의 지각에 영향을 미친다. 자음이 초성에 위치할 경우, 종성에 위치할 경우보다 더 잘 들린 다. 그러나 한국어는 종성에 올 수 있는 자음이 7개로 제한됨으 로써 18 개의 어두 초성보다 더 잘 지각될 수도 있다(Chang, 
2011). 어중 초성의 경우, 주변 모음의 도움을 받아 더 잘 지각 되는 경우도 있으며, 음운 변동 현상으로 인해 영향을 받게 된 다. 아동을 위한 말지각 검사의 개발에 있어서 이러한 음운론 적 요인들이 반드시 고려되어야 할 것이다.

본 연구는 2 3세 아동들의 문장지각 능력을 측정할 수 있고, 코스웨어형 그림 자극을 통해 아동의 반응성을 증가시킬 수 있 는 발달적으로 적합한 다양한 검사 문장을 개발하고자 하였다. 본 연구의 연구 문제는 다음과 같다.

첫째, 영유아 말지각 검사를 위한 문장의 의미론적 구성이 적절히 이루어졌는가?

둘째, 영유아 말지각 검사를 위한 문장의 음운론적 구성이 적절히 이루어졌는가?

셋째, 영유아 말지각 검사를 위한 문장의 구문론적 구성이 적절히 이루어졌는가?

\section{MATERIALS AND METHODS}

\section{예비 연구}

\section{연구 대상}

충남권 대도시 내의 교회와 어린이집, 태권도 학원에 다니는 만 2 3세(17명) 및 만 7 8세(18명) 정상발달 아동들을 대상으 로 하였다. 아동을 상당 기간 지도한 교회, 어린이집, 또는 학원 교사에 의해 청각 등 감각과 언어 발달에 문제가 없는 것으로 보고된 아동들 중에 부모가 검사 참여에 동의한 아동들을 선정 하였다. 만 2 3세 아동들을 예비 연구의 대상으로 선정한 이유는 본 연구의 결과물인 영유아 말지각 검사가 2 3세 수준의 언어 능력을 가진 아동들을 대상으로 이루어질 것이기 때문이며, 만 7 8세 아동들도 대상으로 선정한 이유는 학령기에 접어든 아동 들에게는 본 검사 문장이 모두 쉽게 이해 및 표현될 수 있어야 하고 2 3세 아동들에 비해 상당히 높은 점수가 나오는 것을 확 인하기 위해서였다. 대상 아동들에 대한 정보는 Table 1과 같다.

\section{연구 방법}

\section{검사 문장 개발}

한국판 맥아더-베이츠 의사소통발달 평가(Korean The MacArthur-Bates Communicative Development Inventories, $\mathrm{K}^{-}$ $\mathrm{M}-\mathrm{B}$ CDI) (Pae \& Kwak, 2006)를 참고하여 4음절 이하, 1 2 단어로 이루어진 42 개의 영유아용 문장을 개발하였다. 이때 우 리말 음소 분포 및 사용 빈도를 고려하였다.
그림 자극 코스웨어 제작

각각의 문장에 대한 그림 자극을 코스웨어 형태의 동작그림 으로 개발하였다. 각 코스웨어는 4 16컷의 그림이 애니매이션 형태로 움직일 수 있도록 제작하였다. $\mathrm{Cha}(2003)$ 와 $\operatorname{Kim}(2009)$ 의 논문을 참고하여 그림의 캐릭터는 특정 만화 캐릭터 등을 사용하지 않고 만 2 3세 아동의 신체와 비슷한 비율인 3등신 인물을 사용하였으며, 인물은 머리와 눈이 동그랗게 제작하였 다. 하얀색 배경에 눈에 피로감을 주지 않는 부드러운 저채색 을 사용하였다. Figure 1은 제작된 코스웨어 컷의 예이다.

\section{연구 절차 및 자료 처리}

언어병리학을 전공하는 2명의 연구자가 2 3세 아동들과 7 8 세 아동들에게 각각 42 개의 목표 문장에 따른 코스웨어를 보 여주고 떠오르는 문장을 말하도록 하였다. 검사의 일관성을 위 하여 한 연구자가 아동들과의 상호작용을 진행하였으며, 다른 한 검사자는 기록과 녹화를 담당하였다.

직접 기록과 녹화된 화면을 분석하여 아동들이 산출한 반응 과 목표 문장과의 일치도를 산출하였다. 일치도는 4 가지 기준 을 충족하는 경우 정반응으로 보았으며, 정반응 1문장당 1점 (총 42점)으로 계산하였다. 목표 문장 산출의 기준은 Appendix 1 과 같다. 2 3세 아동집단과 7 8세 아동집단에 대해 목표 문 장 산출 평균과 표준편차를 구하였으며, 두 집단 간 $t$-검정을 시행하였다.

Table 1. Information of subject

\begin{tabular}{cllr}
\hline \multirow{2}{*}{ Age (years; months) } & \multicolumn{2}{c}{ Gender [n (\%)] } & \multirow{2}{*}{$\mathrm{n}$} \\
\cline { 2 - 3 } & \multicolumn{1}{c}{$\mathrm{M}$} & \multicolumn{1}{c}{$\mathrm{F}$} & \\
\hline 2 (mean: 2;9) & $8(100)$ & $0(0)$ & 8 \\
3 (mean: 3;3) & $2(22.2)$ & $7(77.8)$ & 9 \\
7 (mean: 7;6) & $9(64.3)$ & $5(35.7)$ & 14 \\
8 (mean: 8;3) & $3(75)$ & $1(25)$ & 4 \\
\hline
\end{tabular}

M: male, F: female

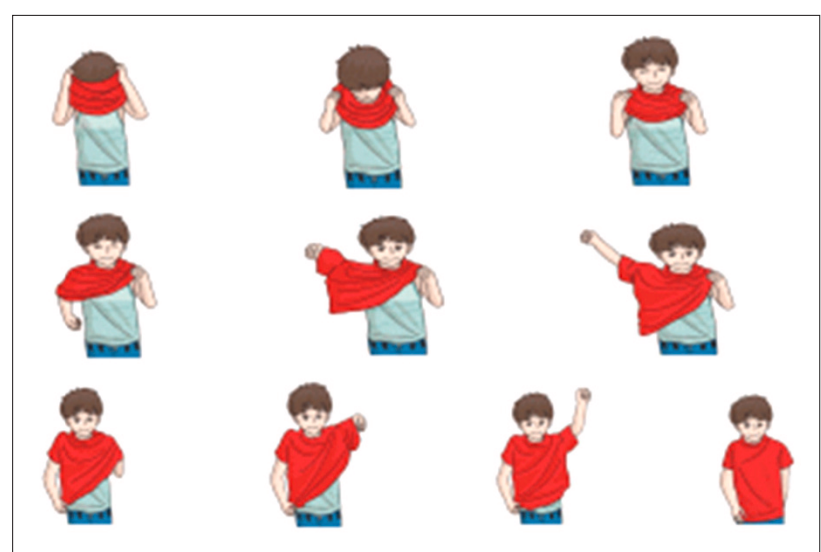

Figure 1. Picture stimuli example of the test sentence '옷입어' (putting on clothes). 
예비연구 결과 및 논의

2 3세 아동집단과 7 8세 아동집단의 목표 문장 표현 점수 를 산출한 결과, 2 3세 아동집단은 평균 19.59[standard deviation (SD): 6.41]였으며, 7 8세 아동집단은 28.94(SD: 4.36)였다. 두 집단 평균에 대한 $t$-검정 결과, $t(33)=-5.074(p<0.001)$ 로 2 3세 아동집단에 비해 7 8세 아동집단의 목표 문장의 표현 점수가 유의미하게 높았다.

2 3세 아동들과 7 8세 아동들은 모두 42개의 그림 자극 코 스웨어를 보고 언어화할 수 있었다. 이를 통해 본 연구의 그림 자극 코스웨어는 아동들이 쉽게 이해하고 산출할 수 있도록 제작되었음을 알 수 있었다. 예상했던 바와 같이 7 8세 아동들 은 2 3세 아동들에 비해 그림 자극 코스웨어를 이해하고 목표 로 하는 문장을 산출하는 능력이 월등하게 높았다. 그러나 2 3 세 아동들은 평균적으로 절반 이하의 목표 문장 산출을 보였 으며, 2 3세 아동집단은 총 12 개의 검사 문장 $(28.5 \%)$ 에서, 7 8 세 아동집단의 경우 총 4 개의 검사 문장(9.52\%)에서 목표 문장 으로 산출되는 경우보다 다른 문장으로 산출되는 경우가 많았 다. 42 개의 문장 중 12 개 문항('내꺼야', ‘바이바이', '못해', '만지 지마' 등)에 대해 코스웨어의 그림을 개선하는 것이 목표 문장 의 이해 및 표현을 향상시킬 수 있을 것으로 판단되었다. 본 예 비 연구를 통해 영유아에게 적합한 문장과 그에 대한 그림 자 극의 제작이 가능함을 알 수 있었으며, 자극 문장과 그림 자극 의 수정 및 보완을 통해 말지각 검사에 사용되는 검사 문장을 개발할 수 있을 것으로 판단하였다.

\section{본 연구}

본 연구에서는 예비 연구의 결과를 바탕으로 어휘 선정과 그 림 자극 제작이 영유아 아동들에게 보다 더 적합하게 이루어 지도록 하고자 하였다. 영유아 아동들의 말지각 검사에 사용될 수 있는 자극 문장을 예비 연구에 사용된 것보다 더 많이 개발 하기 위한 어휘 선정 작업을 거쳐 선정된 어휘에 대한 의미론 적, 음운론적, 구문론적 요소에 따른 분석을 시행하였으며, 선 정된 어휘에 대한 그림 자극 코스웨어를 제작하였다.

\section{연구 대상}

말지각 검사 문장을 개발하기 위해 3세 이하의 정상 발달 영 유아 아동들이 이해하거나 표현할 수 있는 어휘를 조사하였다. 조사 대상은 영유아 아동인구에 사용될 수 있는 표준화된 어 휘 검사, 말지각 및 어음청각 검사 등 검사 도구에 사용된 어휘 리스트와, 학령전기 아동들의 어휘에 대한 연구, 영유아 아동 용으로 시중에 널리 판매되고 있는 출판된 학습교재 및 동화책 등이었다.

표준화된 검사도구로는 수용 및 표현 어휘력 검사(recep- tive-expressive vocabulary test) (Kim et al., 2009)와 한국판 맥아더-베이츠 의사소통발달 평가(K-M-B CDI) (Pae \& Kwak, 2006), 국립특수교육원 말지각 발달 검사(Korean National Institute of Special Education-Developmental Assessment of Speech Perception) (Song et al., 2011)와 어음청각검사(Lee et al., 2010)에서 2 3세 아동 수준으로 사용된 어휘들을 살펴보았 다. 연구 논문으로는 학령전기 아동들의 말지각 검사에 사용될 수 있는 명사 어휘 목록을 조사한 Huh(2012)의 연구와 Chang et al.(2013)의 영유아용 기초 어휘 연구를 참고하였으며, 시판 되는 영유아용 학습교재와 동화책으로는 프뢰벨에서 출판된 한글 학습 시리즈, 시공사에서 출판된 아동도서 등을 조사하 였다. 이러한 조사 과정을 거쳐 2 3세 아동들이 사용하는 어휘 영역에 해당하는 말지각 검사용 어휘 목록을 선정하였다.

\section{어휘 선정의 원리 및 기준}

검사 어휘의 선정 기준은 Chang et al.(2013)의 5가지 기준, 즉 1) 높은 사용 빈도, 2) 넓은 사용 범위, 3) 일상생활 어휘, 4) 발 달적 적합성, 5) 시대에 맞는 어휘를 충족하도록 하였으며, 이러 한 기준에 더하여 영유아를 대상으로 하는 말지각 검사에서 효 율적으로 사용될 수 있도록 6) 우리말 구어 음소 분포 비율을 맞추었고, 청각적 수용 능력을 고려하여 7) 3단어, 4음절 이하 의 길이를 가진 문장으로 구성하여 총 7가지 기준으로 어휘를 선정하였다.

\section{RESULTS}

본 연구의 결과는 의미론적, 음운론적, 구문론적 요소의 분 석으로 이루어졌으며, 의미론적 분석은 품사별, 의미 범주별, 빈 도별 분석이 시행되었고 음운론적 분석은 음절 및 음소 분석, 구문론적 분석은 검사 문장 및 검사 세트 분석이 시행되었다. 마지막으로 코스웨어 그림 자극의 개발에 대한 내용을 정리하 였다.

\section{의미적 요소의 분석}

\section{품사 분석}

선정된 검사 어휘는 명사 62개(36.7\%), 동사 67개(39.6\%), 부 사 12개(7.1\%), 형용사 20개(11.8\%), 조사 8개(4.7\%)로 이루어졌 으며 총 102 개의 문장을 구성하였다. 문장에 사용된 어휘들은 영유아기로 제한되었기 때문에 반복적으로 나타나는 경우가 있었다. 명사는 '물’이 2번 반복되어 총 61가지(43.9\%)가 사용되 었고, 동사의 경우 '가다' 동사가 '가, 가자, 가지마, 갈게, 갔어'의 형태로 5 회, '먹다' 동사가 '먹어'의 형태로 2회, 쓰다' 동사가 '써' 
의 형태로 2회, '앉다' 동사가 '앉아'의 형태로 2회, '오다' 동사가 '와요, 왔어?'의 형태로 2회, '주다' 동사가 '주세요' 1 회, '줘’ 2회 로 총 3회, '타다' 동사가 '타'의 형태로 3회, '하다' 동사가 '하지 마' 1회, '전화해', '사랑해, '응가해, '빨리해', '못해', '또해, '조용히 해'의 형태로 7회 나타났다. 결과적으로 서로 다른 동사의 총 가지 수는 48가지(34.5\%)였다. 부사는 반복되어 사용된 경우가 없었으며(8.6\%), 형용사는 “뜨겁다가 '뜨거워'의 형태로 2회, '아 프다'가 '아파'의 형태로 2회, '크다'가 '커, 크다'의 형태로 2회 사 용되어 서로 다른 형용사의 가지 수는 총 17 가지(12.2\%)였다. 조사의 경우 '에'가 3회, '야'가 4회 사용되어 총 가지 수는 3가 지(2.2\%)였다. 따라서 102 개의 문장에 사용된 총 단어의 개수 는 169 개이고 반복된 단어를 제외하면 총 141 가지의 어휘가 사 용되었다. 품사 분석에서 '명사 + 하다’와 '부사 + 하다’의 형태는 동사로, 의성/의태어는 부사로 분석하였다. 또한 '안돼', '못해', '내꺼야, '하지마', '이리와, '안아줘', '코자요', '가지마'는 유아어 의 특성상 하나의 단어로 분석하였다. 원형의 품사에 대한 분 석은 빈도 분석에서 시행하였다.

\section{의미 범주 분석}

선정된 서로 다른 어휘 139 개를 K-M-B CDI와 Chang et al. (2013)에서 사용한 18 개 범주로 분석하였다. 분석 결과는 Appendix 2 와 같다. 또한 사용된 의미 유형과 각 의미 유형이 어 떠한 의미 관계로 산출되었는가에 대한 분석을 실시하였으며 (Kim, 2014), Table 2에 정리하였다.

\section{빈도 분석}

검사 문장에 사용된 어휘의 빈도를 분석하였다. 빈도 분석은 Sejong Plan Corpus(2011)와 Yonsei Corpus(2002)를 비교하 여 시행하였으며, 세종계획말뭉치는 어휘 위주로, 연세말뭉치 는 어근 위주로 분석하였다.

본 연구에 사용된 어휘들 중에 세종계획말뭉치에서 가장 높 은 빈도를 보인 어휘는 '이'(66,648회)였다. 연세말뭉치에서 가 장 높은 빈도를 보인 어근은 '었'(1,298,833회)이었고, 어휘로는 '물'(189,820회)이었다. 가장 낮은 빈도를 보인 어휘는 세종계획 말뭉치에서 '까꽁', '내꺼', '피나다', '찢었다', '숨었다', '시끄럽다', '의자, '주스', '칠해'(각 1회)였으며, 연세말뭉치에서는 '코끼리'가 9회로 가장 낮았다. 세종계획말뭉치에는 '빵빵', '전화하다', ‘응 가', '깨졌어', ‘바이바이', ‘뽀뽀', '유모차', '냠냠'이 없었으며, 연세 말뭉치에 없는 어휘나 어근은 없었다. 본 연구의 어휘들은 전반 적으로 고빈도 어휘였으며, 세종계획말뭉치 분석으로는 평균 1312.772 회 사용된 어휘들이었고, 연세말뭉치 분석으로는 평균 258073.5회 사용된 어휘들이었다.

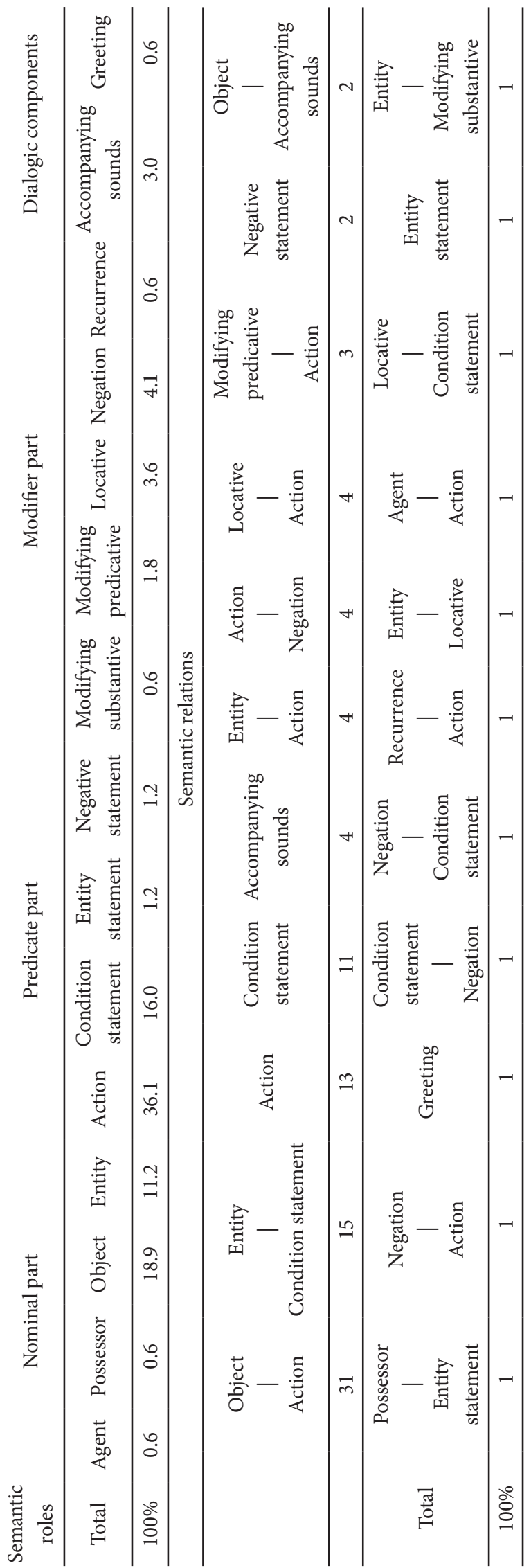




\section{음운론적 요소의 분석}

\section{음절 분석}

1음절로 구성된 한 단어 문장은 매우 제한되어 있으므로 2 음절 이상의 길이를 가진 어휘를 선택했으며, 영유아의 청각적 수용력을 고려하여 문장의 길이는 1 3단어 조합, 4 음절 이하의 길이가 되도록 조절하였다. 총 102 개의 문장들 중에 2 음절 문 장은 13 개, 3 음절 문장 47 개, 4 음절 문장 42 개이며 총 음절 수 는 335개이다. 전체 문장은 Appendix 3에 제시하였다.

\section{음소 분석}

음소 분석은 각 문장을 한글 간략전사법으로 전사하여 자모 음 분석과 음소 위치 분석을 시행하였다. 즉, 한글 철자가 아니 라 발음된 음소를 기준으로 하여 분석하여 영유아의 말소리 환경에서 발생하는 음소와 비교할 수 있도록 하였다.

자모음 분석에서 사용된 총 모음은 331 개, 자음은 328 개이 며, 음소별 빈도는 Figure 2와 같다. 가장 많이 사용된 모음은

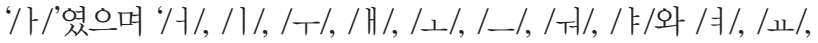

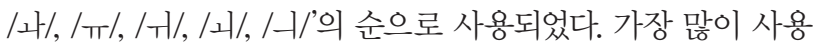

된 자음은 "리”이었으며, \%ㅁ/, /ㄱ/, /ㄴ/, /ㅈ/, /ㅂ/, /ㅅ/과 /O/, /ㄲ//, /ㄸ/, /ㄷ/, /ㅆ/, /치, /E/, /ㅃ/, /ㅎ/, /피/, /ㅋ/, /ㅉ/의 순으로 사용되었다.

모음 중 단모음은 285 개, 이중모음은 46 개로 대부분 단모음 이 사용되었다. Figure 3 을 보면 단모음 중에서 혀의 고저별로 저모음이 $35.7 \%$ 로 가장 많은 비중을 차지하고 있었으며, 고모 음(27.2\%), 중모음(23.3\%), 이중모음(13.8\%)의 순으로 줄어들었 다, 혀의 전후에 따라서는 중설모음 $(57 \%)$, 전설모음 $(27 \%)$, 후설 모음(16\%)의 순으로 분포가 줄어드는 양상을 보였다.

한편 자음의 경우, 조음 위치에 따라 치조음(39\%)이 가장 많 이 사용되었고 양순음(23\%), 연구개음(21\%), 경구개음 $(13 \%)$, 성 문음(4\%)의 순으로, 발달적 순서와 우리말 빈도 분포와 유사하 게 사용되었다. 조음 방법별로는 파열음(37\%)과 비음(27\%)이 $60 \%$ 이상을 차지하였고, 파찰음(13\%), 유음(12\%), 마찰음(11\%) 이 $10 \%$ 를 조금 넘는 수준으로 사용되었다(Figure 4).

본 연구에 사용된 자음의 음절 내 위치별 분포는 초성이 270 개, 종성이 58 개로 총 328 개이며, 어두초성(24\%), 어중초성 (58\%), 어중종성(16\%), 어말종성(2\%)의 비율은 Figure 5 와 같 다. 이 또한 우리말의 음소 위치 분포와 유사한 결과이다.
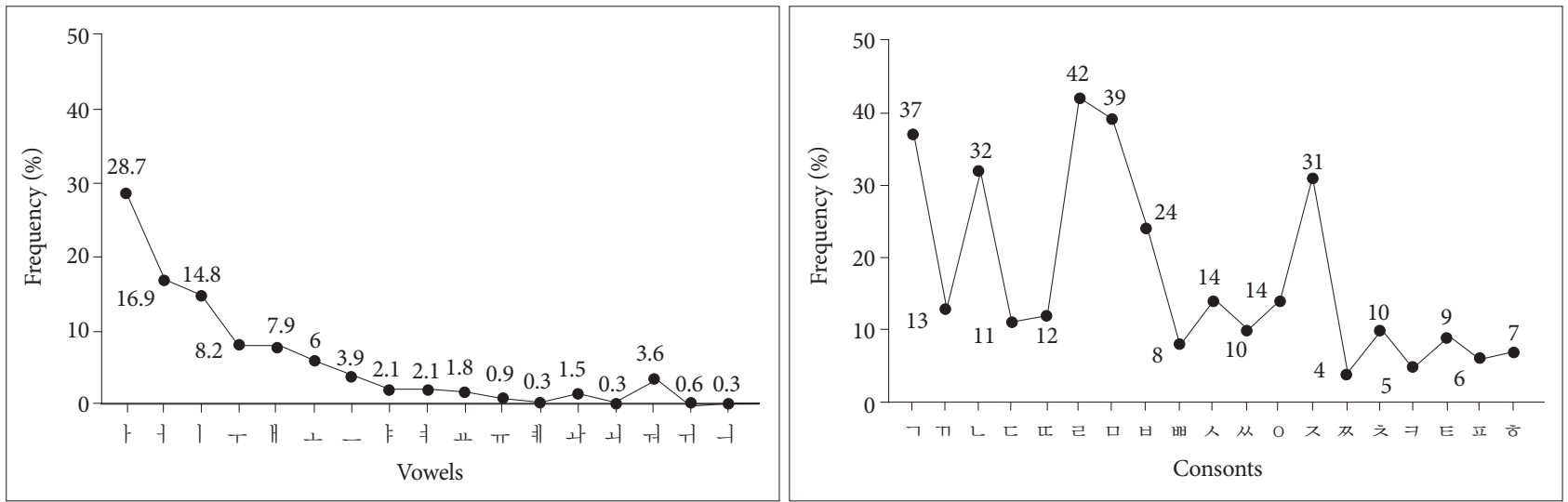

Figure 2. Vowel and consonant frequency of the selected vocabularies.

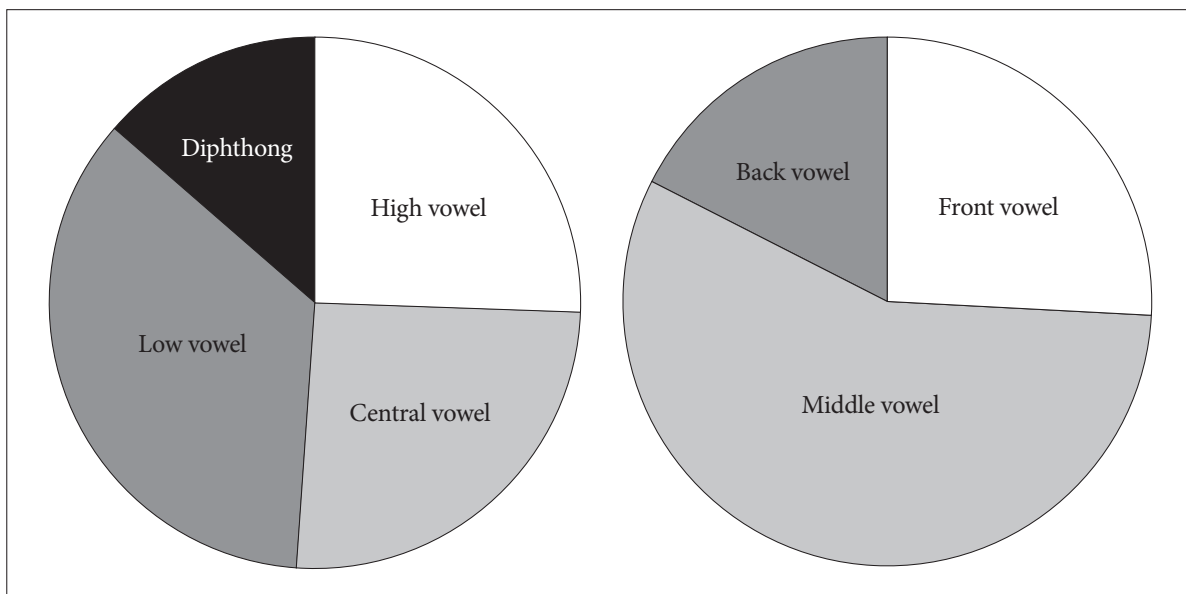

Figure 3. Vowel distribution of the selected vocabularies. 
Figure 4. Consonant articulation place and manner distribution of the selected vocabularies.

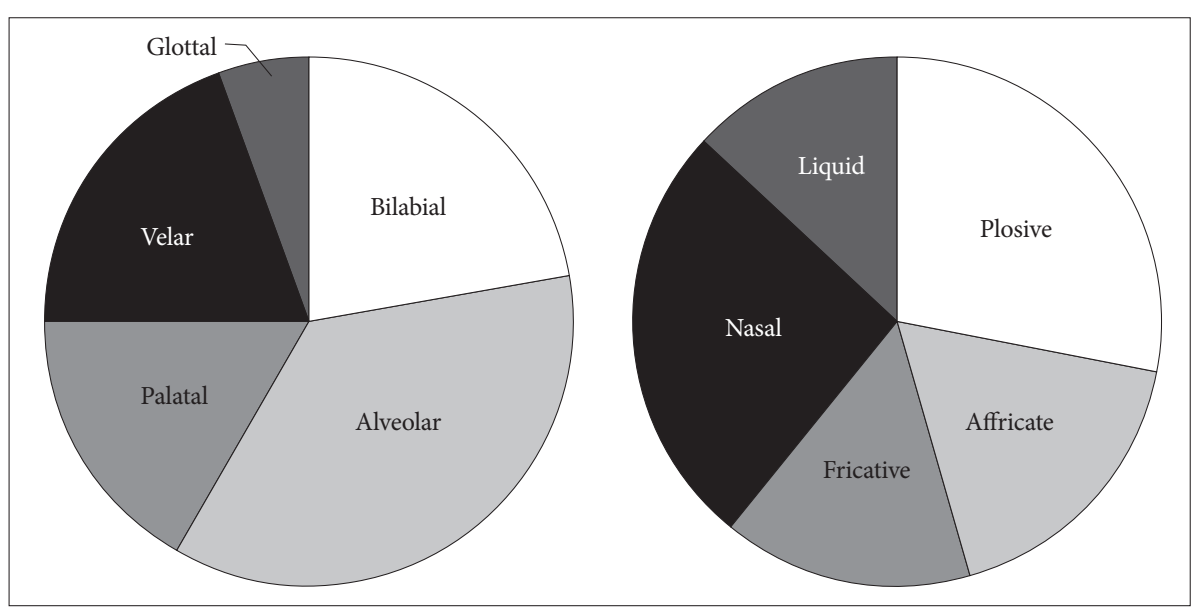

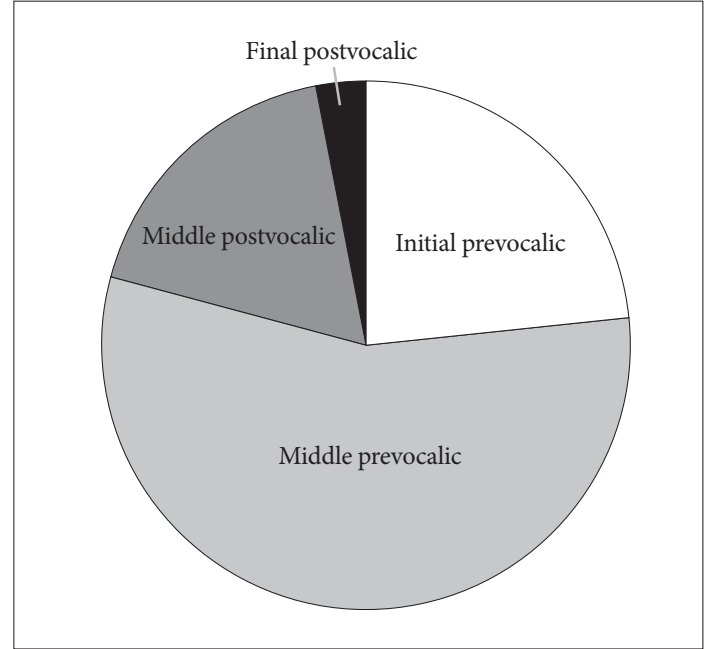

Figure 5. Proportion of consonant within syllable structures in the selected vocabularies.

\section{구문론적 구성 요소의 분석}

\section{검사 문장 구성}

검사 문장은 1 3개의 어휘로 이루어진 문장으로 구성되었다. 하나의 어휘로 이루어진 문장은 연습 문항인 '엄마'와 '앉아'를 포함하여 단일 단어(예: ‘빵뺑'), 동사 또는 형용사(예: ‘놀자, '뜨 거워') 등 총 37 개였고, 2 개의 어휘로 이루어진 문장은 명사 + 동사(예: ‘그림그려') 38개, 명사 + 조사(예: ‘누구야?') 3개, 명사 + 명사('아가뽀뽀') 1 개, 명사 + 부사(사과냠냠') 1 개, 부사 + 동 사(예: '금방갈게') 7 개, 명사 + 형용사(예: ‘공주예뻬') 10 개로 이 루어져 있다. 3 개의 어휘로 이루어진 문장은 명사 + 조사 + 동 사('집에가') 1 개, 명사 + 명사 + 조사(예: '의자위에') 2 개, 명사 + 조사 + 형용사(예: ‘밑에있어') 2개가 있다. Figure 6은 검사 문장의 어휘 조합 분포를 그래프로 나타낸 것이다.

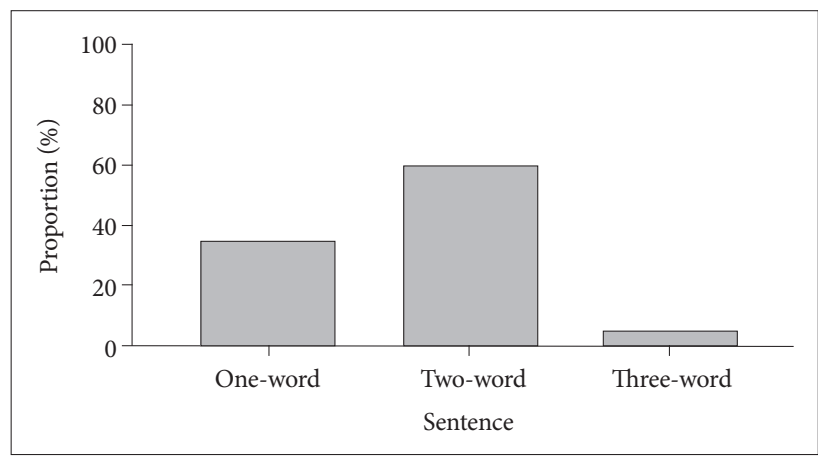

Figure 6. Distribution of word combination in the test sentences.

\section{검사 문장 세트 구성}

개발된 총 102 개의 문장을 10 개씩 총 10 세트로 개발 및 구성 하였고, 2 개의 예시 문장을 제작하였다. 각 세트는 $2,3,4$ 음절 문장이 고르게 분포되도록 하였으며, 음소 및 음절 배열이 고 르게 분포되도록 하였다.

\section{그림 자극 코스웨어 제작}

예비 연구를 통해서 아동들이 지각하기 어려워하는 그림 자 극에 대한 수정을 진행하였으며(예: 바이바이, 내꺼야 등) 부가 적으로 개발된 검사 문장에 대한 그림 자극 코스웨어를 제작 하였다. 하나의 코스웨어당 16 컷을 넘지 않도록 했으며 집중 시 간을 고려하여 작동하는 시간은 5 초를 초과하지 않도록 하였 다(Culpepper \& Thompson, 1994).

\section{DISSCISIONS}

본 연구는 초기 발달 어휘들을 이용하여 3세 이하 수준의 언 어 능력을 가진 검사 대상자들의 문장 지각 능력을 측정할 수 있는 말지각 검사용 문장을 개발하고자 하였다. 또한 검사 문 장에 상응하는 코스웨어형 그림 자극을 개발하여 검사의 반응 성과 이해도를 증가시키고자 하였다. 3 세 이하의 영유아 인구 
는 선행 경험, 집중력, 검사 상황에 따른 변이성으로 인해 절차 를 따르는 검사가 어려운 집단이다. 그러나 중재 초기에 말소리 의 지각 능력을 파악하는 것이 이후의 말-언어 발달을 위한 중 재에 중요한 정보를 줄 수 있기 때문에 이러한 여러 가지 검사 시행상의 어려움에도 불구하고 최대한의 반응을 이끌어내야 할 필요성이 있는 집단이기도 하다.

예비 연구 결과, 7 8세 아동들은 90\% 이상, 2 3세 아동들은 $70 \%$ 이상 42 개의 그림 자극을 보고 목표로 하는 검사 문장을 산출할 수 있었다. 예비 연구를 통하여 아동들에게 친숙한 검 사 어휘와 그림 자극을 선정하고, 특히 2 3세 수준의 아동들에 게 적합하도록 검사 어휘와 그림 자극을 수정하였다. 이를 바탕 으로 개발된 102 개의 검사 문장(예비 문항 '엄마', '앉아' 포함)은 3단어 이하(조사 포함), 4음절 이하로 구성되었으며 그림 자극 은 4 16컷의 그림이 애니매이션 형태의 움직이는 코스웨어형 으로, 사용된 인물과 색채는 아동 인구에게 가장 적합하도록 수정을 거쳤다. 이는 기존의 명사 위주의 폐쇄형 말지각 검사에 서 제공할 수 있는 정보에 부가하여 3세 이하의 영유아기 아동 들의 초기 문장 지각 능력의 발달에 대한 중요한 정보를 제공 하고 적절한 중재로 연결될 수 있도록 도움을 줄 수 있을 것으 로 보인다. 본 연구에서 개발한 말지각 검사 문장이 영유아 인 구에게 효과적으로 사용될 수 있도록 다각적인 분석을 시행하 였고 분석에 대한 논의는 다음과 같다.

\section{의미론적 분석}

아동일수록 말지각 검사에 어떤 어휘가 사용되는가가 중요 하다(Lee \& Lee, 2011). 본 연구는 Chang et al.(2013)의 기준 과, 말지각 검사에 사용될 때 영향을 미치는 구어 음소 분포, 청각적 수용 능력을 부가적으로 고려하여 발달적, 시대적으로
적절한 어휘를 선정하였다. Figure 7은 Chang et al.(2013)의 영 유아 기초 어휘 연구에서 선정한 604 개 어휘들의 품사 분포와 본 연구에서 사용한 어휘들의 품사 분포를 비교한 것이며, 본 연구는 동사 및 형용사, 부사의 사용 비율을 의도적으로 높이 고자 했던 바 Chang et al.(2013)의 기초 어휘의 비율 분포보다 동 사, 형용사 및 부사의 비율이 다소 높았다. 제한된 어휘로 문장 을 구성하였기 때문에 총 29개의 어휘(17.3\%)가 반복 사용되었 으며, 반복된 어휘를 제외하고 서로 다른 어휘의 품사분포를 산 출하면 보다 기초 어휘의 분포에 가까워지는 것을 알 수 있었 다. 어휘는 명사, 동사, 형용사, 부사, 조사의 순으로 줄어들었으 며 문장의 구성을 위해 조사가 사용되었다. 대명사는 명사의 범주에 넣어서 분석하였고 Chang et al.(2013)에서 선정된 수 사, 관형사, 감탄사는 그림 자극으로 구성하기 어려우므로 제외 하였다.

의미 범주는 K-M-B CDI와 Chang et al.(2013)의 연구와 비 교하여 볼 때 영유아들에게 빈번하게 노출되는 18 개의 범주를 모두 포함하고 있었다. '짹짹'과 '냠냠'과 같은 어휘는 소리 지각 을 돕는 의성어의 비율을 높이기 위해 사용하였고, '공주'는 만 화나 동화책에서 빈번히 사용되는 어휘로 추가하였으며, '금방' 은 구어에서 사용되는 어휘를 반영하고자 하였고, '묶어' '풀어', '칠해', '만져', '찢어'는 모두 동사로, 서술 어휘를 증가시키기 위 해 추가되었다.

이러한 의미 범주 분석은 제한된 유아어 분석에 사용되는 틀 로서 의미의 관계 구분을 약하게 할 수 있다. 이에 유아어의 의 미 체계에 화용적 기능을 감안하여 의미 유형 및 의미 관계 분 석을 실시하였다. 본 검사 문장은 4 가지 문장 요소(체언부, 용 언부, 수식부, 대화 요소)를 모두 포함하고 있었으며, 개발의 목 적에 맞게 행위(36\%)와 대상(18.9\%)이 가장 높은 비율로 사용

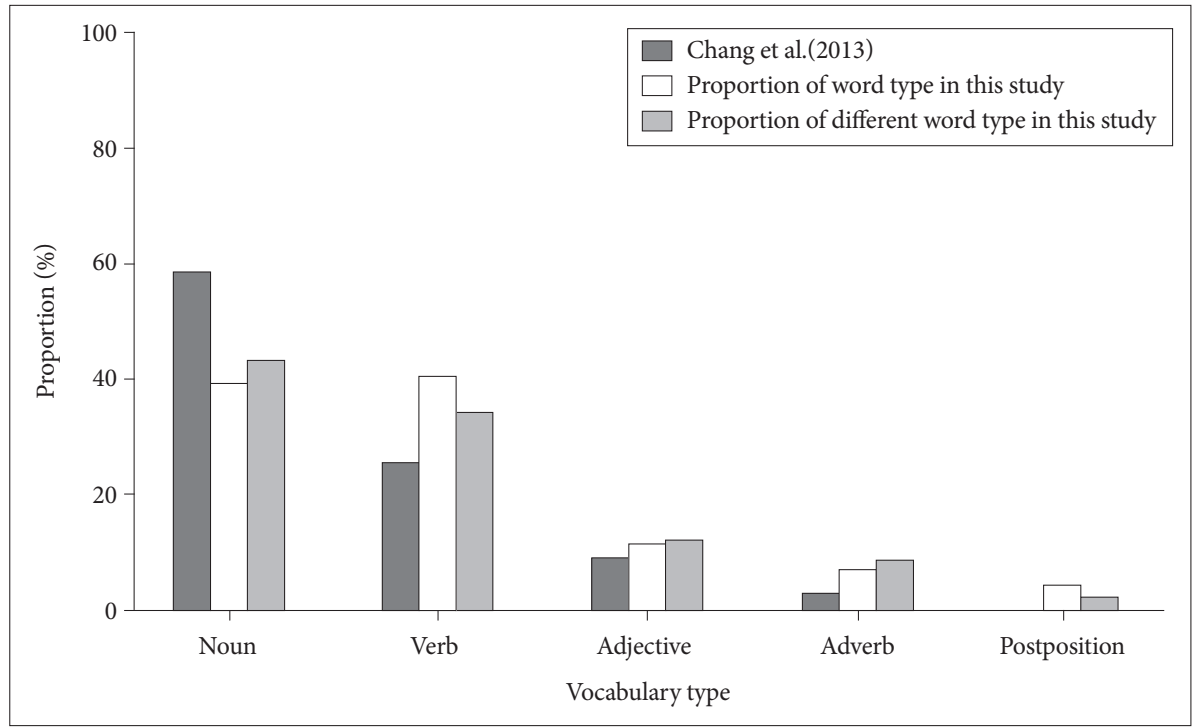

Figure 7. Distribution of vocabulary type in the test sentences. 
되었다. 의미관계는 1 가지 의미관계가 $32 \%$ 를 차지하고 나머지 는 2 가지 의미관계를 가지고 있었으며 $10 \%$ 이상을 차지한 의 미 관계는 대상-행위, 실체-상태 서술, 행위, 상태 서술로 영유 아기에 주소 사용되는 의미 관계를 잘 반영하고 있었다.

어휘 빈도 분석은 우리나라에서 주로 사용되는 2 가지 주요 한 말뭉치를 사용하여 시행했다. 본 검사 문장의 141 개 어휘 중 에 8개의 어휘가 Sejong Plan Corpus(2011)에서는 나타나지 않 았고, 검사 문장의 평균 빈도는 약 1,313회였으나 Yonsei Corpus(2002)에서는 141개 모두 나타났고, 평균 빈도는 약 258,073 회였다. 이렇게 말뭉치 간에 상이한 결과를 보인 것은 말뭉치의 표집이 누구를 대상으로 어떻게 이루어지는가에 따라 빈도 수 에 큰 영향을 준다는 것을 알 수 있는 결과였다. Sejong Plan Corpus(2011)에 비해 Yonsei Corpus(2002)가 구어 중심으로 말표본이 표집된 것으로, 문어 자료에는 빈번히 사용되지 않으 나 구어에서 나타날 수 있는 어휘가 충분히 반영된 것으로 볼 수 있다. 두 말뭉치 모두 유아어에 대한 적절한 빈도 분포를 산 출하기에는 제한이 있지만 본 검사 어휘의 평균 사용 빈도 수 는 모두 높은 수치를 보여 검사 어휘가 영유아의 일상 환경에 서 적절히 사용되고 있다고 볼 수 있는 근거가 되었다.

\section{음운론적 분석}

본 연구는 문장의 특징을 살리기 위해 1음절 단어를 제외하 였고 문장의 구성을 위해 4음절까지의 검사 어휘를 사용하였 다. 이를 $\operatorname{Huh}(2012)$ 의 어휘들과 비교한 결과, 음절 분포에 있어 서 $\operatorname{Huh}(2012)$ 는 1 3음절 명사 어휘를 같은 비율로 선정한 데 비해, 본 연구는 2 4음절의 문장 중 3음절과 4음절 문장이 더 높은 비율로 분포하였다(Figure 8). 이러한 음절의 길이는 청각 적 수용력에 부담을 줄 수 있는 요인이 될 수 있을 것이다. 여러
연구자들은 시각적 강화 요소가 어린 아동들의 청각적 반응을 유의미하게 향상시킬 수 있다고 하였으므로(Greenberg et al., 1978; Primus, 1988; Thompson et al., 1992), 제작된 움직이는 그림 자극이 영유아 아동들의 검사 문장에 대한 청각적 부담을 해소하는 요인으로 작용할 수 있을 것이다. 명사 위주가 아닌 서술어를 포함한 문장 자극을 영유아 아동들이 받아들이는 양 상과, 그림 자극의 효과에 대한 후속 연구가 필요할 것이다.

본 연구의 검사 문장들은 말지각 검사에 사용되어야 하므로 우리말에 발생하는 구어 음소 빈도, 특히 아동 인구에서 발생 하는 빈도 수에 대한 고려가 반드시 필요하다. 3 8세 아동들의 자발화에서 모음과 자음의 발생 빈도를 조사한 $\operatorname{Shin(2005)ㅇㅢ~}$ 연구와 영유아 말지각 검사용 명사 단어 선정에 대한 $\operatorname{Huh}(2012)$ 의 결과를 본 연구와 비교한 결과는 Figure 9와 같다.

그래프를 보면, 모음의 경우 $\operatorname{Huh}(2012)$ 에 비해 본 연구가 아 동 발화에서의 발생 비율과 더 유사한 것을 알 수 있다. 그러나 자음은 전반적으로 다른 연구들에 비해 고르게 사용되었으며, ‘/ᄀ/,' ‘ㄴ/, ‘/ㄷ/의 경우 발화에서의 발생과 $\operatorname{Huh(2012)ㅇㅢ~ㅇㅓㅎㅟ~}$ 보다 상당히 적게 사용되었으며 ‘리의 사용 빈도가 증가하였 다. 이는 특히 자음의 경우, 말지각 검사로서의 유용성 측면에 서 발생 빈도를 고려하면서도 모든 자음을 검사하여 청각장애 아동들이 특히 어려움을 겪게 되는 자음지각에서의 문제를 밝 히기 위해 의도적으로 이루어진 것이며, 실제 적용을 통해서 유용성을 검증할 필요가 있다. 'ㄹ'의 경우 지각과 산출 모두에 서 어려울 수 있는 자음이므로 추후 이에 대한 분석이 이루어 져야 할 것이다.

Figure 2 5를 보면, 본 검사 문장에 사용된 모음은 단모음과 이중모음의 비율, 전설 모음과 후설 모음의 비율, 저/중/고 모음 의 비율이 아동 발화에 사용된 비율과 유사한 양상을 보이고

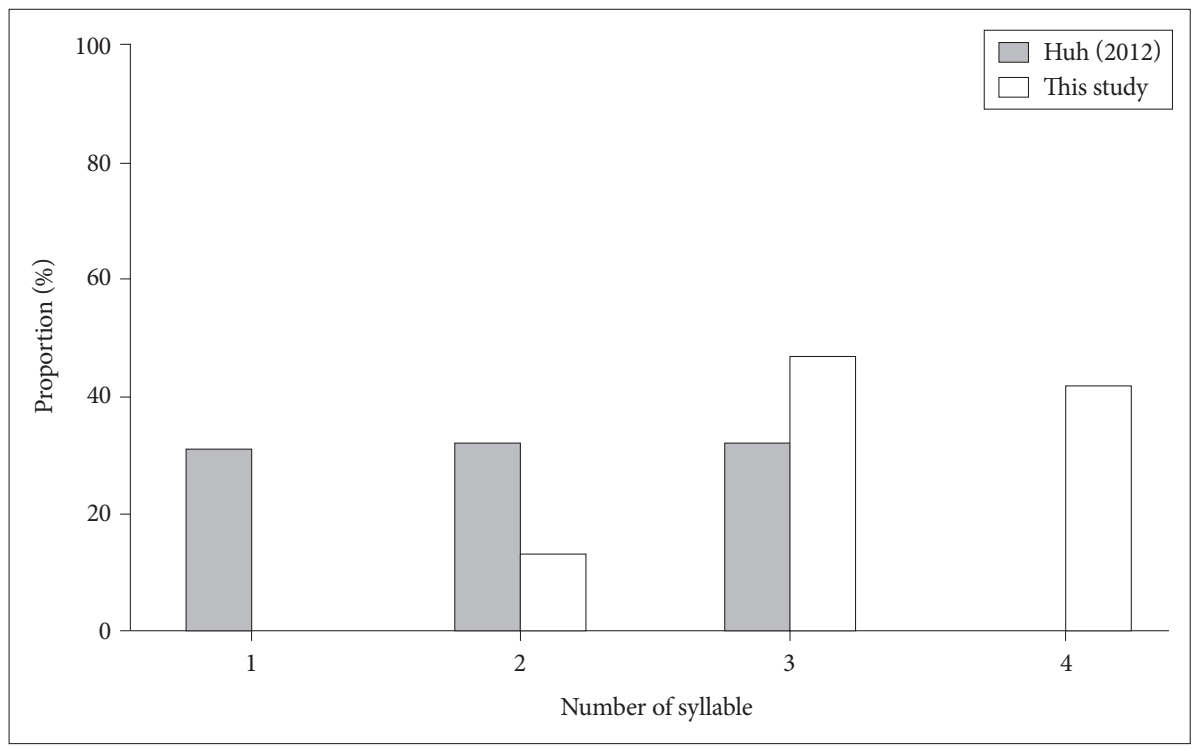



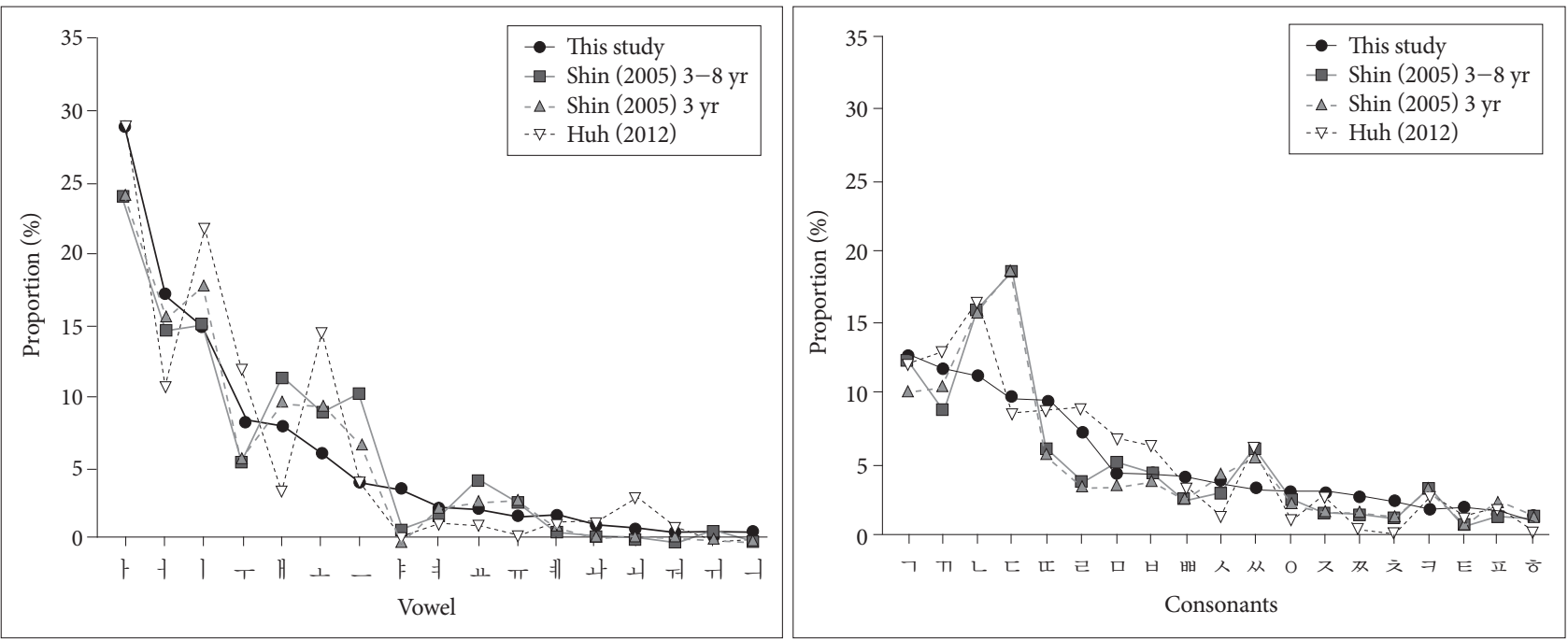

Figure 9. Comparison of vowel and consonant analysis.

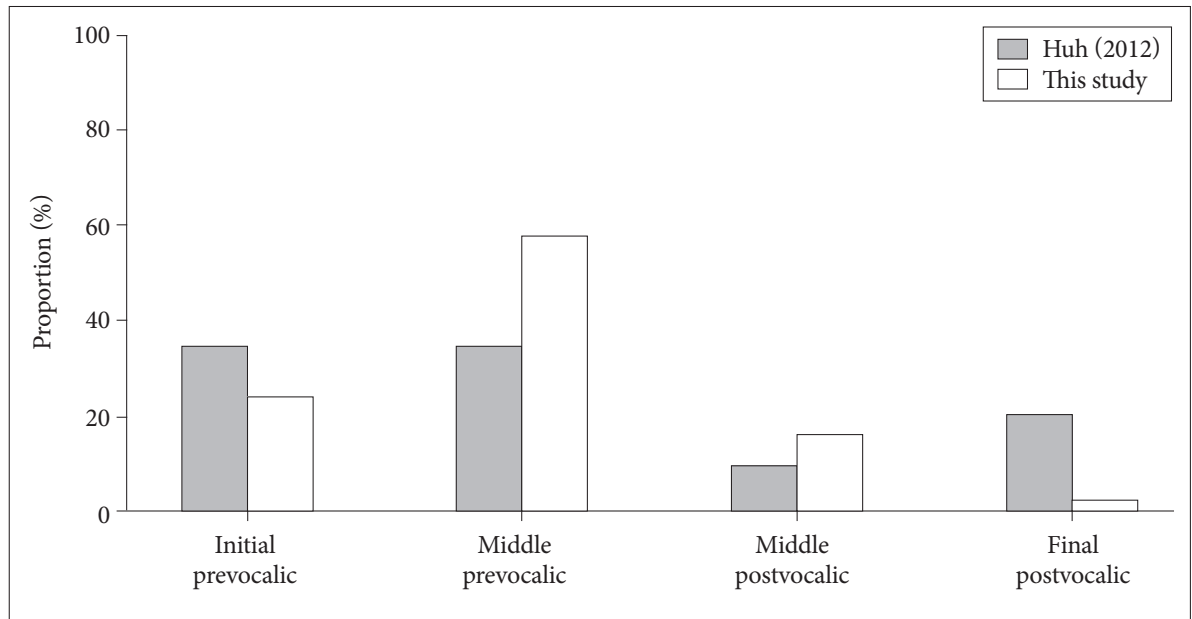

Figure 10. Comparison of consonant within syllable structures in the test sentences.
있었으며(Kim \& Shin, 2015), 자음의 분포 또한 조음 방법에서 폐쇄음과 비음이 $60 \%$ 이상을 차지하고 조음 위치에서 치조음 이 절반 가량을 차지하는 등 아동 발화의 일반적인 양상과 일 치하고 있다. 그러나 중모음보다 저모음이 더 높은 비율을 차지 하고 있으며 양순음의 비율이 높은 것은 선행 연구와 약간의 차이를 보이는 결과이다.

Figure 10은 본 연구에 사용된 검사 문장의 음절구조와 Huh (2012)의 명사 검사 자극의 음절구조를 비교한 것이다. 본 검사 문장의 음절 구조에서 명사 자극에 비해 어두초성과 어말종성 의 사용 비율이 적고 어중초성과 어중종성의 사용 비율이 높은 것을 알 수 있었다. Kim \& Shin(2015)에 의하면, 1 2세 50 낱 말기에 주로 발생하는 음절구조는 $\mathrm{CV}$ 형이 $56 \%$ 로 가장 많은 비중을 차지하였다. 한편 V형 $21 \%, \mathrm{VC}$ 형 $15 \%, \mathrm{CVC}$ 형 $8 \%$ 로, 종성자음이 있는 형태의 음절구조가 $23 \%$ 를 차지하는 것을 알 수 있다. 이러한 비중 분포를 보면 아동의 연령이 증가하면서 자연스럽게 $\mathrm{V}$ 형 발화가 줄어들고 $\mathrm{CV}$ 가 연속되는 형태로 진전
되므로, $\operatorname{Huh}(2012)$ 의 음절구조나 본 연구의 음절구조나 2 3세 아동들에게 받아들여지기에 적절한 분포라고 할 수 있을 것이 다. 한편 우리말 문장의 특성상 서술 어휘에서 어말 종성의 사 용이 드물며, 본 연구의 음소 분석은 단어나 어절로 이루어지 지 않았고, 음성전사를 한 구어형태로 이루어졌기 때문에 어말 종성의 빈도가 줄어든 결과가 나타난 것으로 보인다. 종성 자 음이 7개로 제한되는 우리말의 특성상 어중에 위치할지라도 지 각적인 어려움이 덜어질 수 있다. 그러나 이는 검사 자극의 산 출 시 아동들의 조음 발달 측면에서 더 불리한 조건이 될 수 있 으며, 폐쇄형 검사와 개방형 검사 간의 점수 차이를 가져올 수 있는 요인이 될 수 있을 것이다.

\section{검사의 구문론적 요소 및 그림 자극 코스웨어 분석}

본 연구의 검사 문장은 주로 2단어 문장 $(60 \%)$ 으로 이루어져 있으며, 1 3단어가 사용되었다. 3단어 문장인 경우에도 하나의 단어는 주로 문장을 구성하기 위한 조사였다. 즉, 아동들의 의 
미론적 처리에 대한 부담을 덜어주기 위해 하나 또는 2 개의 의 미적 단서만이 포함될 수 있도록 한 것이다. 또한 기존의 유아 용 말지각 검사는 1 개의 검사 세트가 사용되는 경우도 많았고 대부분 최대 2 3개의 검사 세트로만 이루어져 있는 데 비해 10 개의 검사 세트를 구성할 수 있는 많은 자극을 개발함으로써 말지각 검사로서의 유용성을 높이고자 하였다. 이는 문장검사 결과에 영향을 미치는 학습 효과를 최소화하고 아동의 언어 능력에 영향받을 수 있는 가능성을 줄일 수 있을 것이다. 각 검 사 세트는 음소 및 음절 분포에서 동형성을 갖추도록 하였으 며, 실제 검사 시행을 통해 내적 신뢰도 검증이 이루어져야 할 것이다.

영유아기에 사용되는 제한된 어휘로 많은 문장을 개발함으 로써 명사로 이루어진 단어 자극에 비해 난이도가 높아지는 문 제는 코스웨어형 그림 자극이 부가적으로 사용됨으로써 어느 정도 해소될 수 있도록 하였다. 즉, 검사 문장이 개방형 검사로 사용될 경우에는 아동의 문장 산출에 대한 강화의 역할을 할 수 있도록 코스웨어 그림 자극을 사용하고, 폐쇄형으로 사용 될 경우에는 코스웨어 그림 자극을 보기로 사용함으로써 의미 론적 단서 역할을 하여 말지각 검사 문장으로서의 유용성을 높이고자 하였다. 예비 연구에서 살펴보았듯이, 3 세 이하의 어 린 아동들은 그림 자극을 이해하고 해석하는 능력이 떨어지므 로 개발된 그림 자극에 대한 추후 검증이 필요할 것이다.

본 연구는 3 세 이하의 영유아 아동들에게 사용될 수 있는 문장형 말지각 검사와 그에 따른 코스웨어형 그림 자극을 개발 하는 것을 목적으로 하였다. 검사 문장은 명사만을 사용한 검 사에 비해 동사, 형용사, 부사, 조사 등 여러 가지 품사를 포함 하고 있으며 아동들에게 적절한 의미 범주에 초점을 맞추었고, 음절 수나 음소적 차원에서 어린 아동들에게 최대한 부담이 되지 않도록 구성하였다. 음소와 음절에 대한 타당성은 검증하 였으나 아동용 말뭉치를 사용하여 어휘의 빈도 측면에 대한 추 후 연구가 필요하다. 또한 생동감 있는 코스웨어형 그림 자극을 개발함으로써 검사의 범위를 넓히고자 하였다. 검사 문장의 타 당성 검증을 위한 다각적인 분석을 시행하였으며, 이는 실제 검 사로서의 유용성과 타당성, 신뢰성 검증이 다각적으로 이어져 야 할 것이다. 즉, 단어 수준이 아닌 문장 수준의 검사이므로 문장의 운율적 요인에 대한 추후 연구가 보다 유용한 검사 개 발을 위해 필요할 것으로 보인다. 또한 2세 수준의 아동들은 성 별에 따른 차이를 크게 보일 수 있는 연령대로서, 연구 대상의 성비의 균형을 맞추고 이에 대한 분석을 진행해야 할 것이다. 본 연구에서 개발한 영유아 말지각 검사 문장과 코스웨어 그림 자극이 아동들의 말 산출 반응을 촉진하여 말지각 능력에 대 한 많은 정보를 제공할 수 있기를 기대해 본다.
중심 단어 : 말지각 검사·영유아 문장·그림 자극.

\section{Acknowledgments}

본 연구는 한국연구재단 산학협력 선도대학(LINC) 육성사업 산 학공동기술개발과제(2L9-2-01)의 일부로 시행되었습니다. 연구에 동의해 주신 부모님과 아이들에게 감사드립니다.

\section{REFERENCES}

Best, C. C. \& McRoberts, G. W. (2003). Infant perception of non-native consonant contrasts that adults assimilate in different ways. Language and Speech, 46(2-3), 183-216.

Blamey, P. J., Sarant, J. Z., Paatsch, L. E., Barry, J. G., Bow, C. P., Wales, R. J., et al. (2001). Relationships among speech perception, production, language, hearing loss, and age in children with impaired hearing. Journal of Speech, Language, and Hearing Research, 44(2), 264-285.

Byun, S. W., Chung, S. M., Kim, H. S., \& Go, Y. M. (2005). A survey of phonetically balanced words lists used in training hospitals in Korea. Korean Journal of Otolaryngology-Head and Neck Surgery, 48(9), 1086 1090.

Cha, E. Y. (2003). Study on the inclination of preference for boys and girls in children's picture book: In three to seven-year-old children (unpublished master's thesis). Sookmyung Women's University, Seoul.

Chang, H. J., Jeon, H. S., Shin, M. S., \& Kim, H. J. (2013). A study on selection of basic vocabulary for infants and toddlers. Journal of Speech and Hearing Disorders, 22(3), 169-187.

Chang, S. A. (2011). Frequency-limiting effect on perception of speech and environmental sound in normal-hearing and cochlear implant adults (unpublished doctoral dissertation). Yonsei University, Seoul.

Choi, K. B. (2000). The role and function of lexical clssified system in the extension of word meaning. The Linguistic Association of Korea Journal, 8(2), 177-195.

Culpepper, B. \& Thompson, G. (1994). Effects of reinforcer duration on the response behavior of preterm 2-year-olds in visual reinforcement audiometry. Ear and Hearing, 15(2), 161-167.

Davidoff, J. \& Masterson, J. (1996). The development of picture naming: Differences between verbs and nouns. Journal of Neurolinguistics, 9(2), 69-83.

DeCasper, A. J. \& Fifer, W. P. (1980). Of human bonding: Newborns prefer their mothers' voices. Science, 208(4448), 1174-1176

Eimas, P. D., Siqueland, E. R., Juscyk, P., \& Vigorito, J. (1971). Speech perception in infants. Science, 171(3968), 303-306.

Greenberg, D. B., Wilson, W. R., Moore, J. M., \& Thompson, G. (1978). Visual reinforcement audiometry (VRA) with young Down's syndrome children. Journal of Speech and Hearing Disorders, 43(4), 448-458.

Huh, M. J. (2012). Lexicon study for speech recognition battery of young children: In terms of syllable. Journal of Speech-Language and Hearing Disorders, 21(1), 145-155.

Jang, Y. S. (2004). A study on the design and implementation of educational web courseware for improving cognitive ability of mildly mental retarded students (unpublished master's thesis). Chonnam National University, Gwangju.

Kajikawa, S., Fais, L., Mugitani, R., Werker, J. F., \& Amano, S. (2006). Crosslanguage sensitivity to phonotactic patterns in infants. The Journal of the Acoustical Society of America, 120(4), 2278-2284.

Kim, J. Y. (2009). A study of digital 3D animation character design for infants (unpublished master's thesis). Sejong University, Seoul.

Kim, S. J. (2014). Phonological error patterns of conversational speech produced by 2- and 4-year-old children. Communication Sciences and Disorders, 19(3), 361-370.

Kim, S. J. \& Shin, J. Y. (2015). Speech Sound Disorder. Seoul: Hakjisa.

Kim, W., Cheon, J., Choi, K., \& Choi, S. H. (2016). A content word analysis in elementary school 1-2 graders' Korean textbooks for vocabulary teaching of school age children with language impairment: Focused on 
comparison before and after the 2009 revision. Audiology and Speech Research, 12(3), 176-181.

Kim, Y. T. (2014). Assessment and Treatment of Language Disorders in Children. (2nd ed.). Seoul: Hakjisa.

Kim, Y. T., Hong, K. H., Kim, K. H., Jang, H. S., \& Lee, J. Y. (2009). Receptive and Expressive Vocabulary Test; REVT. Seoul: Seoul Community Rehabilitation Center.

Korean Audiological Society (2015). Speech Perception Test in Practice. Seoul: Hakjisa.

Lee, H. R. (2009). A longitudinal study of emergence of the first verb and maternal linguistic inputs. Journal of Speech and Hearing Disorders, 18(1), 1-15.

Lee, J. H., Cho, S. J., Kim, J. S., Jang, H. S., Lim, D. H., Lee, K. W., et al. (2010). Korean Speech Audiometry. Seoul: Hakjisa.

Lee, M. Y. \& Lee, J. H. (2011). Lexical effects on word recognition of adults and children with normal hearing. Audiology, 7(2), 219-228.

Ministry of Culture, Sports and Tourism, The National Institute of the Korean Language. (2011). Sejong Plan Corpus: 21st Century Sejong Plan Final Achievement (DVD). (2nd ed.). Seoul: Ministry of Culture, Sports and Tourism, The National Institute of the Korean Language.

Pae, S. Y., \& Kwak, K. J. (2006). Korean The MacArthur-Bates Communi- cative Development Inventories. Seoul: Mind Press.

Primus, M. A. (1988). Infant thresholds with enhanced attention to the signal in visual reinforcement audiometry. Journal of Speech and Hearing Research, 31(3), 480-484.

Robbins, A. M. (1994). The Mr. Potato Head Task. Indianapolis, IN: Indiana University School of Medicine.

Shin, J. (2005). Phoneme frequency of 3 to 8 -year-old Korean children. Korean Linguistics, 27, 163-200.

Song, Y. J., Lee, H. J., \& Jang, H. S. (2011). Korean National Institute of Special Education-Developmental Assessment of Speech Perception: KNISEDASP. Seoul: Kyoyookbook.

Thompson, G., Thompson, M., \& McCall, A. (1992). Strategies for increasing response behavior of 1-and 2-year-old children during visual reinforcement audiometry (VRA). Ear and Hearing, 13(4), 236-240.

Trehub, S. E. (1976). The discrimination of foreign speech contrasts by infants and adults. Child Development, 47, 466-472.

Werker, J. F. \& Desjardins, R. N. (1995). Listening to speech in the first year of life: Experiential influences on phoneme perception. Current Directions in Psychological Sciences, 4(3), 76-81.

Yonsei Institute of Language and Information Studies. (2002). Yonsei Corpus. Seoul: Yonsei Institute of Language and Information Studies. 


\section{APPENDICES}

Appendix 1. Examples of Criteria for Production of Target Sentences

\begin{tabular}{ll}
\hline \multicolumn{1}{c}{ Criteria } & \multicolumn{1}{c}{ Examples } \\
\hline Exact production of target sentences & '문닫아' $\rightarrow$ '문닫아' \\
Production of target sentences with semantic elaboration & '앉아요' $\rightarrow$ '의자 앉아요' \\
Semantically same representation to the target sentences & '뛰어가' $\rightarrow$ '달려가' \\
Production of verbs in target sentences representing same semantic relations & '코자요' $\rightarrow$ '잠자요' \\
\hline
\end{tabular}




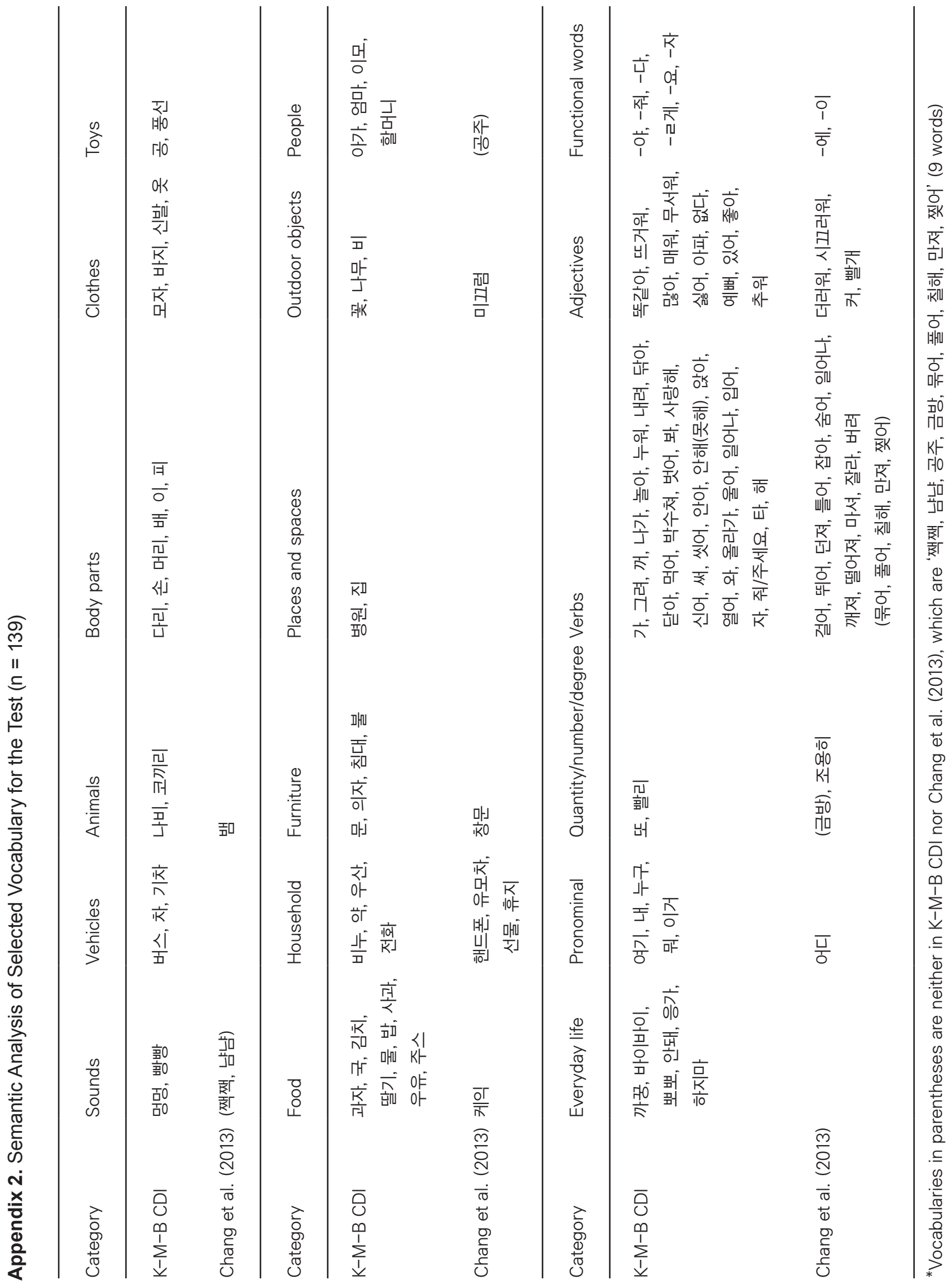


Appendix 3. 102 Sentences for Infants and Toddlers Developed in this Study Except Example Sentences of '엄마' and '앉아'

\begin{tabular}{|c|c|c|c|c|c|c|c|c|c|}
\hline No. & Sentence & No. & Sentence & No. & Sentence & No. & Sentence & No. & Sentence \\
\hline 1 & 버스타 & 21 & 빵빵 & 41 & 약먹어 & 61 & 나가자 & 81 & 만지지마 \\
\hline 2 & 할머니야 & 22 & 깨졌다 & 42 & 여기앉아 & 62 & 물틀어 & 82 & 바이바이 \\
\hline 3 & 모자써 & 23 & 딸기씻어 & 43 & 침대누워 & 63 & 하지마 & 83 & 없다 \\
\hline 4 & 코자요 & 24 & 올라가 & 44 & 코끼리커 & 64 & 바지벗어 & 84 & 내꺼야 \\
\hline 5 & 밥먹어 & 25 & 옷입어 & 45 & 숨었다 & 65 & 핸드폰줘 & 85 & 일어나 \\
\hline 6 & 추워요 & 26 & 시끄러워 & 46 & 주세요 & 66 & 문닫아 & 86 & 우유좋아 \\
\hline 7 & 케익잘라 & 27 & 휴지버려 & 47 & 기차빨라 & 67 & 배아파 & 87 & 울지마 \\
\hline 8 & 풍선불어 & 28 & 김치맵다 & 48 & 집에가 & 68 & 공주예뻐 & 88 & 놀자 \\
\hline 9 & 멍멍 & 29 & 유모차타 & 49 & 불꺼 & 69 & 비누칠해 & 89 & 못해 \\
\hline 10 & 물내려 & 30 & 주스마셔 & 50 & 많아요 & 70 & 선물풀어 & 90 & 밑에있어 \\
\hline 11 & 비와요 & 31 & 짹짹 & 51 & 사랑해 & 71 & 까꿍 & 91 & 빨리해 \\
\hline 12 & 우산써 & 32 & 걸어가 & 52 & 다리아파 & 72 & 과자줘 & 92 & 이게뭐야 \\
\hline 13 & 신발신어 & 33 & 전화해 & 53 & 떨어져 & 73 & 안아줘 & 93 & 안돼 \\
\hline 14 & 아가뽀뽀 & 34 & 꽃이빨개 & 54 & 찢었다 & 74 & 의자위에 & 94 & 이거봐 \\
\hline 15 & 차타자 & 35 & 병원가자 & 55 & 피났어 & 75 & 이모왔어 & 95 & 똑같다 \\
\hline 16 & 그림그려 & 36 & 뛰어가 & 56 & 금방갈께 & 76 & 조용히해 & 96 & 어디갔어 \\
\hline 17 & 미끄럼타 & 37 & 뜨거워 & 57 & 사과냠냠 & 77 & 이닦아 & 97 & 누구야 \\
\hline 18 & 손잡아 & 38 & 국뜨거워 & 58 & 더러워 & 78 & 싫어 & 98 & 가지마 \\
\hline 19 & 응가해 & 39 & 나무크다 & 59 & 뱀무서워 & 79 & 머리묶어 & 99 & 이리와 \\
\hline 20 & 창문열어 & 40 & 나비날아 & 60 & 공던져 & 80 & 박수쳐 & 100 & 또해 \\
\hline
\end{tabular}

